\title{
The Effect of Village Formation on Regency/City Regional Finance in Papua Province
}

\author{
Anita Erari \\ Faculty of Economics, Cenderawasih University \\ Jl. Kamp. Wolker, Waena, Jayapura, 99358, Papua, Indonesia \\ Phone/Fax.: +62-967-585470; E-mail: aerari@yahoo.co.id
}

DOI: 10.31957/plj.v3i2.786

\begin{abstract}
According to Minister of Home Affairs Regulation No. 56 of 2015 concerning Code and Data of Administrative Area, it is mentioned that Papua is one of 34 provinces in Indonesia with the highest number of villages by 5,419 villages, 110 urban villages, and 558 sub-districts scattered in 28 regencies and 1 city. The high number of villages in a regency/city area has an effect on the amount of village funds allocated by the Central or Provincial Governments for each district/city, thus affecting the amount of regency/city APBD. Village Fund Allocation is a manifestation of the fulfillment of the right for the village to implement the principle of autonomy for the village to grow and develop following the growth of the village itself, based on diversity, participation, original autonomy, democratization, and community empowerment. However, the increasing number of village formation burdened the government budget to finance the formation of new villages, so that the village formation had a significant and positive effect on the amount of regional finance, especially regency/city and provincial APBD. For example, in the 2016 fiscal year, Tolikara Regency had a total of 541 villages spreading across 46 districts and received the largest village fund allocation of Rp320.04 billion. Thus, Tolikara Regency ranked 1st with the most villages and the largest village fund in the Papua Province. In contrast, Jayapura City with a total of 13 villages was the regency/city with the least number of villages and the least amount of village fund of Rp. 12.51 billion.
\end{abstract}

Keywords: Village; Village Fund

\section{INTRODUCTION}

In order for the acceleration of the implementation of village development to accommodate the community order, the Government promulgated Law No. 6 of 2014 concerning Village (Law 6/2014 on
Village) ${ }^{1}$. The Law places villages as the spearhead of development and enhances the community welfare. Villages are given great opportunities to manage the governance and implement its own development. The aim is for village communities to be

\footnotetext{
${ }^{1}$ Law of the Republic of Indonesia No. 6 of 2014 on Village.
} 
more independent in managing the government and various existing natural resources. The higher role of the villages is followed by higher responsibility.

The villages have authority and allocation of fund to manage their potential in order to improve the community welfare. The Government allocates a substantial Village Fund every year. In 2015, the allocation of village fund was $\operatorname{Rp} 20.7$ trillion, with an average of Rp 280 million in each village and in 2016 , the allocation of village fund increased to $\mathrm{Rp} 46.98$ trillion with an average of $\mathrm{Rp} 628$ million per village.

The allocation of Village Fund assists village communities to build facilities/infrastructure that benefit the community, including village roads; bridge; clean water facilities; Early Childhood school; village market; Posyandu (Integrated Service Post); and other facilities. The allocation of Village Fund for several villages is used to develop the quality of the community, through training in certain skills and developing small businesses. The development of the quality of human resources in the village is aimed at the community welfare and realizing a common goal.

The government needs to guard and supervise the use of village funds so that their use is on target, for village development with the aim of improving community welfare through the creation of employment opportunities, minimizing economic inequalities, and alleviating poverty. The authority and allocation of village funds provided by the Government to the villages has an effect on the formation of new villages.

Indonesia holds the new record as the country with the most regional expansion. ${ }^{2}$ Since the existence of regional autonomy in 1998, the number of provinces, regencies and cities has increased. Based on the survey of the Central Statistics Agency (BPS in 2010), the number of provinces in Indonesia is 33 provinces, increasing by seven provinces since the enactment of Law No. 22 of 1999 concerning Regional Government. The number of regencies and cities in Indonesia in

\footnotetext{
www.detik.com//IndonesiaNegaraEkspansi// online edition June 9, 2011
} 
2010 was 399 regencies and 98 cities. In 2016, there were 34 provinces and 508 regencies/cities in Indonesia. Data in 1998 showed only 27 provinces and 293 regencies/cities. There has been an increase since the governance model changed from the top-down to bottom-up development model with the enactment of Law No. 22 of 1999 and Government Regulation No. 129 of 2000 which was later replaced by Government Regulation No.78 of 2007 concerning Requirements, Formation and Criteria for Regional Expansion, Elimination and Merger.

According to the Regulation of the Minister of Home Affairs Regulation No. 56 of 2015 concerning Code and Data of Administrative Area, it is stated that Papua Province is one of 34 provinces in Indonesia with the highest number of villages of 5,419 villages, 110 urban villages and 558 sub-districts spreading over 28 regencies and 1 city $^{3}$. In the entrepreneurial village post showing the number of villages in Indonesia in 2015, Papua Province ranked 4th in the list of "Provinces

\footnotetext{
${ }^{3}$ Regulation of Minister of Home Affairs No. 56 of 2015 on Code and Data of Administrative Area.
}

with the Most Villages in Indonesia" below Central Java Province (Rank 1st with a total of 7,809 villages), East Java Province (Rank 2nd with a total of 7,724 villages) and Aceh Province (Rank 3rd with 6,474 villages).

The results of studies from BAPPENAS and UNDP in 2008 showed that the performance of new autonomous regions (NARs) was below the parent regions (areas of origin of NAR). This is due to several things, it can be seen that regional expansion encourages the migration of the poor from the parent area to the NAR, because the available data showed that the poor were concentrated in the NAR. Poverty is a major problem and challenge that must be resolved in the implementation of decentralization and regional autonomy. Another NAR lag compared to parent region is limited resources, both natural and human resources. From the results of this study, it can be seen that NAR is a region where the majority of people are poor, have limited natural wealth and lagging human resources. As a result, NAR finds difficulty to develop and assist the central 
government in accelerating growth and prosperity.

\section{METHOD}

This study was based on the objective to analyze the position of villages and traditional villages. Thus, this study used exploratory and descriptive approaches. Exploratory approach was used to analyze the initial phenomenon of the research object, while descriptive approach was used to describe the facts of the research object.

The type of research was normative legal research and empirical legal research. Normative legal research was conducted to examine norms or rules and legal concepts related to existing problems. This type of normative legal research was conducted to support empirical legal research. While empirical legal research was used to determine the real nature of law, especially to obtain an overview on the existence of the village in connection with special autonomy in Papua.

\section{DISCUSSION}

\section{Employee Expenditure Dominates Regional Expenditure}

To accelerate the growth and welfare of the people, the local government requires funds as its tool and each region has the right to regulate their respective finances in order to advance development. Simply, the local government cannot advance development if the government does not have funds. It can be seen that the Regional Budget (APBD) until 2010 were mostly spent on employee expenditure.

The Minister of Finance, Agus Martowardojo stated that throughout 2010, the allocation of employee expenditure increased by $\mathrm{Rp} 198$ trillion from Rp 123 trillion in 2009. Meanwhile, the allocation of capital expenditure in the Regional Budget in 2010 was $\mathrm{Rp} 96$ trillion or smaller than the previous year of $\mathrm{Rp} 104$ trillion. "It can be seen that capital expenditure has fallen and employee expenditure has risen," said Agus in the national development planning meeting on Thursday $(28 / 4)^{4}$.

https://nasional.kontan.co.id/news/anggarandaerah-banyak-tersedot-buat-belanjapegawai-1 
According to him, the portion of the employee expenditure allocation in the APBD in 2010 increased to $45 \%$ from $38 \%$ in the previous year. However, the allocation of capital expenditure in the APBD was only 22\%. Referring to this condition, Agus conveyed a solution to allocate more capital expenditure budget for:

1. Rationalizing the expenditure of salaries and benefits for regional civil servants.

2. Improving the quality of APBD expenditure through increasing the percentage of capital expenditure.

3. Directing the

APBD expenditure for activities that support local economic activities, alleviating unemployment and poverty.

This encourages the Minister of Home Affairs, Gamawan Fauzi to call each Governor to review the budget composition of each regency/city, in order to improve and sharpen the budget target for the community. In 2010, the budget allocated transfer to the regions reached $\mathrm{Rp} 344.7$ trillion, which increased by Rp 393 trillion in 2011. Whereas in 2012, the budget allocated transfer plan to regions reached $\mathrm{Rp} 437.1$ trillion. The 2016 APBN-P showed that the initial amount of budget allocated transfer to regions of $\mathrm{Rp}$. 770.2 trillion increased to Rp. 776.3 trillion. With this amount, for the first time in history, the amount of budget allocated transfer to regions was greater than the expenditure of Ministry/Agency. In the 2016 APBN$\mathrm{P}$, total Ministry/Agency expenditures was $\mathrm{Rp} 767.8$ trillion. The increase in the budget allocated transfer to regions was intended to support inclusive growth.

\section{Management of Sectoral Funds by} Regions

The large number of regional expansion apparently did not accelerate development, instead it burdened the government budget to finance civil servants and the daily needs of the government. Regional expansion should not be made to compete in issuing SKPD and getting old-age, survivors insurance. Building a new regional government is not to take the allocated funds as much as possible, but to do the best for this country.

In line with decentralization and the development of regional 
autonomy, the sectoral funds have been converted into regional development assistance funds in the form of General Allocation Funds (DAU) for general assistance or sectoral general assistance in the form of Special Allocation Funds (DAK) where its use is handed over to the regency/city area in accordance with the problems faced and the available potential. With the development funding assistance, it is expected to encourage the growth of economic activity in the community.

Local government finds it difficult to develop development when the allocation of development funds is relatively small. The Papua Provincial Government realizes that efforts to increase funds in the APBD every fiscal year are not easy because the determination of the amount of financial balance funds consisting of the General Allocation Fund (DAU), Special Allocation Funds (DAK) and Revenue Sharing Funds (DBH) consisting of Taxes and Natural Resources have been calculated and stipulated in formula and studies that can be accounted for with the aim of equitable distribution by taking into account the determinants of the amount of funds received, including: regional potential, geographical condition, population and income level of the community, thereby reducing or minimizing the differences between developed region and undeveloped region, especially for Papua, in order to be able to consider the factor of land area.

Land area factor has encouraged regency/city government in the Papua Province to form new autonomous regions, both regencies/cities, districts, and the establishment of new villages. The addition of new autonomous regions has an effect on the addition of funds to the Regency/city APBD. The addition of APDB encourages the development of people's lives to be better, especially in improving the economy of the community, facilitating the improvement of health services, education and fostering adversity quotient to provide the best services to the community and improve community welfare among regions, both at the regency/city, district and village levels.

In Papua, deputy head of the Unit for the Acceleration of Development in Papua and West Papua (UP4B), 
Drs. E. Fonataba, MM, stated that the development of a regency area is determined by Regional Budget (APBD) of the regency. "The reason is because the regional government budget is a driver of the regional economy, provides employment, builds public facilities, mainly roads and bridges to open up regional isolation and provide life for people in the area". According to him, the regional government has the responsibility for the welfare of people's lives. On the basis of this responsibility, the local government is granted the authority to regulate, organize and manage the existing potential and resources for the prosperity of the community. ${ }^{5}$

\section{Village Fund Allocation}

With the aim of people welfare who mostly live in the village, the fund allocation to the village is higher. In 2010, each village received Rp100 million, the amount of village fund allocation given by central government to each village in Papua Province reached a range of $\mathrm{Rp} 720$ million per village in 2016. Whereas based on village fund disbursement data in 2016, it showed a different value of $\mathrm{Rp} 615$ million per village obtained from the total village fund of Rp 3.385 trillion distributed to 5,501 villages spreading across 28 regencies and one city in the Papua Province.

The Village Fund is expected to be self-managed, meaning that it is managed and carried out by the local people. The community can use local raw materials to run the economic wheel of the village, such as using stone, sand, wood and local products. The use of village fund can drive the village economy and increase the income of the villagers. In addition, it can expand employment opportunities where people can get the jobs, have income and can affect the maintenance of security and reduce unemployment and eventually alleviate poverty.

In the future, the greater village funds can be utilized properly, "every cent of village funds is used productively to provide maximum benefits for the improvement of services to the community, improvement of community welfare

${ }^{5}$ http://fonatabae.blogspot.com/2014/03/p embangunan-suatu-daerah-ditentukan.html 
and implementation of equitable development."6

In order to implement equitable distribution of village development towards independence, increase welfare of the village community, and support the implementation of village development, assistance funds need to be allocated to the village in the form of Village Fund Allocation (ADK). ADK, which is a balance fund, is expected to be the main support for the implementation of development and empowerment of village communities, so as to improve the welfare of the village community. Therefore, the regency/city government must allocate the funds from the APBD to the village.

According to Hanif Nurcholis ${ }^{7}$, Village Fund Allocation is the distribution of fund through village cash obtained through the regency/city APBD sourced from the central and regional financial balance funds received by regencies/cities for villages with the portion of at least 10 percent According to Eko Sutoro

\footnotetext{
6 Director General Budiarso, af/waropenkab.go.id

${ }^{7}$ Hanif, Nurcholis. (2011). Pertumbuhan dan Penyelenggaraan Pemerintah Desa. Jakarta: Erlangga Publisher. p. 88-89
}

(2005: 10), ADK is the responsiveness of the state to finance and strengthen village authority, including: the authority of origin (managing natural resources, customary justice, forming original structure, and forming social institution) recognized by the state. Furthermore, the authority of local scale attributes includes: planning, ecological spatial planning, settlement, forming local organization, etc., and the authority of administrative delegation arising from delegation or assistance task from the government ${ }^{8}$.

Whereas according to Wasistiono and Tahir $^{9}$, financing or finance is a factor in supporting the implementation of autonomy principle granted to the village head. To regulate and manage their own household, the village needs and requires sufficient funds as a support to carry out the authority. Thus, the implementation of ADK assistance is an important instrument to become an arena for the community and

8 Eko, Sutoro. (2005). Pembaharuan Otonomi Daerah. Yogyakarta: APMD Press. p. 10

9 Wasistiono, Sadu and Irwan Tahir. (2006). Prospek Pengembangan Desa. Bandung: CV. Fokusmedia. p. 17 
elements managing village governance, such as village government apparatus, and Village Consultative Body (BPK) to foster community participation in realizing responsive and participatory village governance towards public interest. ${ }^{10}$

\section{Effect of Village Formation on Regional Finance}

The provision of Village Fund Allocation (ADK) is a manifestation of the fulfillment of the right for the village to implement the principle of autonomy for the village to grow and develop following the growth of the village itself, based on diversity, participation, original autonomy, democratization, and community empowerment. According to Hanif Nurcholis ${ }^{11}$, the provision of ADK is intended to finance village government programs in carrying out government activities and community empowerment. The objectives of ADK activities are:

1. To improve the administration of village governance in implementing government, development, and community services in accordance with its authority.

2. To improve the capacity of community institution in

\footnotetext{
${ }^{10}$ Ibid. p. 17

${ }^{11}$ Hanif Nurcholis, Ibid. p. 89
}

planning, implementing and controlling participatory development in accordance with the village potential.

3. To increase regional equity and income, employment opportunities and business opportunities for the village community.

4. To encourage increased community self-help.

5. To overcome poverty and reduce inequality.

6. To increase infrastructure development in villages.

7. To increase the practice of religious and socio-cultural values in order to realize social improvement.

8. To increase order and peace in the community.

9. To increase the income of village and community through Village Owned Enterprise (BUMKampung).

The management ADK allocation is an integral part of village financial management in the APBD. All activities financed by $\mathrm{ADK}$ are planned and carried out and evaluated openly by involving all layers of the village community. All activities whose funding comes from ADK must be administratively, technically and legally accountable. ADK is used in a directed, economical, efficient, fair and controlled manner. The amount of ADK other than using fair and equitable principles, shall be proportional to each village by 
considering poverty, basic education, health, affordability factors, and additional factors such as population, land area, economic potential, and community participation.

Table 1 shows the number of villages in each regency/city area in the Papua Province. Based on Table 1 , it can be seen that Tolikara Regency has a total of 541 villages and 4 urban villages spreading across 46 districts. Thus, Tolikara Regency ranks first with the most villages in Papua Province, followed by Yahukimo Regency in the 2nd rank with 510 villages, Lanny Jaya Regency in the 3rd rank with 354 villages, followed by Jayawijaya Regency in 4th rank with 328 villages and Puncak Jaya Regency in the 5th rank with 302 villages. High amount of village funds to villages in the Papua Province area shall be followed by strict supervision by the provincial and regency/city governments in terms of its utilization, management and accountability. The village government shall report the Realization of the Implementation of the Village Budget (APBDesa)

In contrast, Jayapura City with 13 villages is the regency/city with the least number of villages in the Papua Province, but it is also a "regency/ ity with the largest number of urban villages in the Papua Province" by 25 urban village. Jayapura City ranks 1 st with the least number of villages in Papua Province, followed by Supiori Regency in the 2nd rank with 38 villages, Central Mamberamo Regency ranks 3rd with 59 villages, Deiyai Regency in 4th rank with 67 villages and Mamberamo Raya Regency in the 5th rank with 69 villages.

In addition to showing the highest and the least number of villages, Table 1 describes the allocation of village funds received by each regency/city in the Papua Province in 2016. 
Table 1

Number of Villages and Amount of Village Fund Per Regency/City in the Papua Province

\begin{tabular}{clcccc}
\hline Rank & \multicolumn{1}{c}{ Regency/City } & District & Urban Village & Village & Fund (M) \\
\hline 1. & Tolikara & 46 & 4 & 541 & 320.04 \\
\hline 2. & Yahukimo & 51 & 1 & 510 & 300.50 \\
\hline 3. & Lanny Jaya & 39 & 1 & 354 & 213.09 \\
\hline 4. & Jayawijaya & 40 & 4 & 328 & 196.37 \\
\hline 5. & Puncak Jaya & 26 & 3 & 302 & 185.44 \\
\hline 6. & Yalimo & 5 & - & 300 & 181.97 \\
\hline 7. & Pegunungan Bintang & 34 & - & 277 & 172.28 \\
\hline 8. & Biak Numfor & 19 & 14 & 254 & 149.82 \\
\hline 9. & Nduga & 32 & - & 248 & 151.12 \\
\hline 10. & Asmat & 19 & - & 221 & 140.45 \\
\hline 11. & Paniai & 23 & 5 & 216 & 132.51 \\
\hline 12. & Puncak & 25 & - & 206 & 132.59 \\
\hline 13. & Merauke & 20 & 11 & 179 & 120.37 \\
\hline 14. & Mappi & 15 & 2 & 162 & 104.40 \\
\hline 15. & Kepulauan Yapen & 14 & 5 & 160 & 96.27 \\
\hline 16. & Jayapura & 19 & 5 & 139 & 86.26 \\
\hline 17. & Mimika & 18 & 19 & 133 & 85.93 \\
\hline 18. & Boven Digoel & 20 & - & 112 & 75.95 \\
\hline 19. & Waropen & 11 & - & 100 & 64.14 \\
\hline 20. & Intan Jaya & 8 & - & 97 & 69.08 \\
\hline 21. & Sarmi & 10 & 2 & 92 & 62.73 \\
\hline 22. & Keerom & 11 & - & 91 & 59.80 \\
\hline 23. & Dogiyai & 10 & - & 79 & 53.46 \\
\hline 24. & Nabire & 15 & 9 & 72 & 48.64 \\
\hline 25. & Mamberamo Raya & 8 & - & 69 & 51.00 \\
\hline 26. & Deiyai & 5 & - & 67 & 45.39 \\
\hline 27. & Central Mamberamo & 5 & - & 59 & 45.72 \\
\hline 28. & Supiori & 5 & - & 38 & 27.25 \\
\hline 29. & Jayapura City & 5 & 25 & 13 & 12.51 \\
\hline T O T A L & $\mathbf{5 5 8}$ & $\mathbf{1 1 0}$ & $\mathbf{5 , 4 1 9}$ & $\mathbf{3 , 2 4 5}$ \\
\hline Source & Regurion & 5 & 5 & & \\
\hline
\end{tabular}

Source: Regulation of Minister of Home Affairs No. 56 of 2015 concerning Code and Data of Administrative Area, and Attachment XX of Presidential Regulation of the Republic of Indonesia No. 137 of 2015 concerning Details of the 2016 State Budget, proccessed, December 2016.

Tolikara Regency ranks 1st with the largest amount of village funds of Rp320.04 billion for 541 villages; Yahukimo Regency ranks 2nd with a total village fund of Rp 300.50 billion for 510 villages; Lanny Jaya Regency ranks 3rd with a total village fund of Rp213.09 billion for 354 villages; followed by Jayawijaya Regency in 4th rank with a total village fund of Rp196.37 billion for 328 villages and Puncak Jaya Regency ranks 5th with 
a total village fund of $\mathrm{Rp} .185 .44$ billion for 302 villages.

Furthermore, the ranking of recipients of the least amount of village funds in regencies/cities in the Papua Province in the 2016 fiscal year is as follows: Jayapura City ranks 1st with a total village fund of Rp. 12.51 billion for 13 villages; Supiori Regency ranks 2nd with a total village fund of Rp. 27.25 billion for 38 villages; Central Mamberamo Regency ranks 3rd with a total of village fund of Rp. 45.72 billion for 59 villages; followed by Deiyai Regency in 4th rank with a total village fund of Rp. 45.39 billion for 67 villages and Mamberamo Raya Regency ranks 5th with a total village fund of Rp. 51 billion with 69 villages.

From the description above, it can be concluded that higher number of villages within one regency/city area has an effect on the amount of village funds allocated by the Central Government or the Papua Provincial Government for each regency/city and affects the amount of regency/city Regional Budget (APBD) in Papua Province. Thus, the formation of villages has significant and positive effect on regional finance, particularly the provincial and regency/city APBD in the Papua Province.

\section{CONCLUSION}

High number of villages in one regency/city area has an effect on the amount of village funds allocated by the Central or Provincial Governments for each regency/city, thus affecting the amount of the regency/city APBD. Village Fund Allocation is a manifestation of the fulfillment of the right for the village to implement the principle of autonomy for the village to grow and develop following the growth of the village itself, based on diversity, participation, original autonomy, democratization, and community empowerment. However, the increasing number of village formations burdened the government budget to finance the formation of new villages, so that the village formation had a significant and positive effect on the amount of regional finance, especially the regency/city and provincial APBD. 


\section{BIBLIOGRAPHY}

Eko, Sutoro. (2005). Pembaharuan Otonomi Daerah. Yogyakarta: APMD Press.

Hanif, Nurcholis.

(2011).

Pertumbuhan

dan

Penyelenggaraan Pemerintah Desa. Jakarta: Erlangga Publisher.

Wasistiono, Sadu and Irwan Tahir. (2006). Prospek Pengembangan Desa. Bandung: CV. Fokusmedia.

Law of the Republic of Indonesia No. 6 of 2014 on Village.
Regulation of Minister of Home Affairs No. 56 of 2015 on Code and Data of Administrative Area.

Director General Budiarso, af/waropenkab.go.id

https://nasional.kontan.co.id/news/an ggaran-daerah-banyak-tersedotbuat-belanja-pegawai-1

http://fonatabae.blogspot.com/2014/0 3/pembangunan-suatu-daerahditentukan.html

www.detik.com//IndonesiaNegaraEks pansi// online edition June 9, 2011 